\title{
EFFECTS OF GROWTH TEMPERATURE ON POLYSTYRENE ADHESION OF PSEUDOMONAS AERUGINOSA ATCC 27853
}

\author{
Simone Cappello $^{1 *}$; Salvatore P.P. Guglielmino ${ }^{2}$ \\ ${ }^{1}$ Istituto per l'Ambiente Marino Costiero sez. Messina, Istituto Sperimentale Talassografico, Messina, Italy; ${ }^{2}$ Università degli \\ Studi di Messina, Dip. Scienze Microbiologiche, Genetiche e Molecolari, Italy
}

Submitted: September 30, 2004; Returned to authors for corrections: July 13, 2005; Approved: April 19, 2006

\section{SHORT COMMUNICATION}

\begin{abstract}
The importance of avoiding bacterial adhesion to plastic medical devices is recognized. To better understand the interaction between bacteria and surface, we studied the influence of different growth temperatures $\left(15,30\right.$ and $\left.47^{\circ} \mathrm{C}\right)$ on the polystyrene adhesion capacity of Pseudomonas aeruginosa ATCC 27853.
\end{abstract}

Key words: Pseudomonas aeruginosa, temperature, hydrophobicity, adhesion

Pseudomonas aeruginosa is an opportunist pathogen of humans (18) and the major cause of ulceralike keratitis, lung infections, cystic fibrosis, nosocomial infection and a wide range of severe and sometimes fatal diseases in immunocompromised individuals (1).

A number of surface and extracellular components synthesized by $P$. aeruginosa contribute to its virulence, but the capacity to adhere to inanimate and biological surfaces is an important stage in the infectivity. The importance of avoiding bacterial adhesion to contact lenses, intravenous catheters, prosthetic joints, dentures, and other plastic medical devices is generally recognized (17). Bacteria attach to the exterior parts of the implants, migrate along the surface into the interior of the body, and cause severe infections or destroy the implant (14).

Bacteria and other microorganisms have a natural tendency to adhere to surfaces as a survival mechanism and bacterial colonization of solid surfaces has been described as a basic and natural bacterial stratagem in a wide variety of environments $(10,12,15)$.

The initial step in the colonization is a thermodynamic process mediated by non-specific physicochemical interactions $(7,14)$, which depend on nutrient availability and physical stress caused by environmental factors, growth and nutritional status of the bacterial population.

Hydrophobicity of the bacterial cell surface (CSH) is one of the most important factors which govern the mechanism of bacterial adhesion to inanimate and biological surfaces $(7,19)$.

In this work we showed that growth temperature plays a important role in capacity of bacteria to adhere to polystyrene.

Cultures of Pseudomonas aeruginosa ATCC 27853 (ATCC Corp., Manassas, Va., USA) were prepared in Luria Bertani broth (Difco, Milan, Italy). Mid-exponential-phase grown cells were harvested by centrifugation at $11.250 \mathrm{x} g$ for $10 \mathrm{~min}$, washed twice with $0.9 \% \mathrm{NaCl}(\mathrm{w} / \mathrm{vol})$, and inoculated to a final concentration of $3 \times 10^{8}$ cell $/ \mathrm{mL}\left(\mathrm{A}_{600 \mathrm{~nm}}=0.3\right)$ in $\mathrm{M} 9$ minimum salt medium (Sigma-Aldrich, Milan, Italy), supplemented with $4 \%$ glucose. Cells were incubated in Erlenmeyer flasks at 15, 30 and $47^{\circ} \mathrm{C}$ for 7 days with shaking (Certomat IS B. Braun Biothec International, $80 \mathrm{rpm}$ ). For the assay of adhesion to polystyrene, $20 \mathrm{~mL}$ of bacterial culture were withdrawn from the flask of culture every $12 \mathrm{~h}$. The cells were washed twice in PBS buffer and suspended to a final concentration of $3 \times 10^{8}$ cell $/ \mathrm{mL}$. Ten $\mathrm{mL}$ of the suspension were transfered to $60 \mathrm{~mm}$ polystyrene Petri plates and incubated for $30 \mathrm{~min}$ at $30^{\circ} \mathrm{C}$ without shaking, to study the initial adhesion process.

*Corresponding Author. Mailing address: Istituto per l'Ambiente Marino Costiero (IAMC) sez. Messina Istituto Sperimentale Talassografico (IST) CNR Messina. Spianata S. Ranieri, 86 I-98122 Messina, Italy. Phone.:+39-090-669003 Fax.:+39-090-669007 E-mail: simone.cappello@iamc.cnr.it 
The capacity of polystyrene adhesion was measured as percentage of hydrophobicity, (\%HP), calculated using the following equation:

$$
\% \mathrm{HP}=\text { O.D } \text { init }_{\text {- }} \text { O.D } \mathrm{D}_{\exp } \times 100 / \mathrm{O}_{\text {init }}
$$

where O.D init and O.D exp were the optical densities of the suspension before and after incubation of the polystyrene plate, respectively.

Alls experiments were repeated three times, using two parallel cultures for each experiment.

The adhesion of $P$. aeruginosa ATCC 27853 to polystyrene, measured as percentage of hydrophobicity (\%HP), is reported in Fig. 1. The results evidence that the temperature of bacterial growth can influence the capacity of $P$. aeruginosa ATCC 27853 to adhere to polystyrene. The bacteria appeared to be more hydrophobic during cultivation at $47^{\circ} \mathrm{C}$ that in other temperatures.

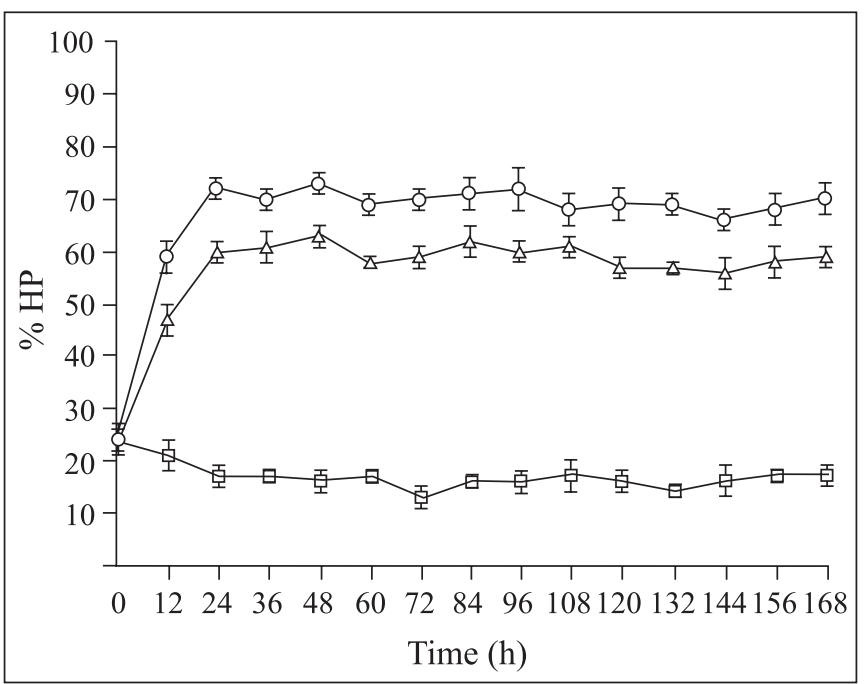

Figure 1. Effect of temperature on adhesion, as percentage of hydrophobicity (\%HP) of Pseudomonas aeruginosa ATCC 27853 to polysyrene. $15^{\circ} \mathrm{C}$ (square), $30^{\circ} \mathrm{C}$ (triangle) and $47^{\circ} \mathrm{C}$ (circle).

During growth a $15^{\circ} \mathrm{C}$, the value of $\% \mathrm{HP}$ presented a decrease in the first $48 \mathrm{~h}$, passing from a value of $\% \mathrm{HP}=24$ in time zero to $\% \mathrm{HP}=16$ in $48 \mathrm{~h}$ and remaining constant afterwards. At $30^{\circ} \mathrm{C}$, the curve of percentage of hydrophobicity presented an increase in the first $24 \mathrm{~h}$, passing from a value of $\% \mathrm{HP}=24$ to $\% \mathrm{HP}=60$ and maintaining stable in this value for the whole period of observation.

At $47^{\circ} \mathrm{C}$ the capacity of adhesion to polystyrene increased progressively with time of cultivation reaching a plateau in
$24 \mathrm{~h}$. After increasing from $\% \mathrm{HP}=24$ (time zero) to $\% \mathrm{HP}=59$ in the first $24 \mathrm{~h}$, the capacity of adhesion remained constant with an average value of $\% \mathrm{HP}=72$.

In general, nondifferentiating bacteria respond to changing environmental conditions by using a number of adaptive survival mechanisms. These mechanisms include a rapid change in the pattern of gene expression, often manifested both physiologically and structurally (4). Changes in bacterial attachment characteristics under stress may be linked to changes in cell surface hydrophobicity and in components of the bacterial outer membrane involved in attachment, such as pili and lipopolysaccharides (LPSs). The expression of these structures may change depending on the environment to which the bacterium exposed.

It has recently been reported that P-pili mediated binding of $E$. coli induces a cascade of virulence factors, being the virulence genes transcribed more efficiently at higher growth temperatures (21). The surface charges and hydrophobicity of L. monocytogenes were also influenced by the environmental temperature (2), explaining the variation of the bacteria in the ability to adhere to substrates.

In conclusion, temperature is an abiotic factor that dramatically influences the capacity of adhesion and, indirectly, the hydrophobicity surface of Pseudomonas aeruginosa. This consideration is very important to explain the pathogenesis of this bacterium, so that proper measures can be taken to avoid bacterial adhesion to medical devices, specially in nosocomial environment.

\section{RESUMO}

\section{Interferência da temperatura de cultivo na adesão de Pseudomonas aeruginosa ATCC 27853 ao poliestireno}

A importância de evitar a adesão bacteriana aos dispositivos médicos plásticos é reconhecida. Para melhor comprender a interaçao entre bactérias e superfices, este estudo avaliou a influência de diferentes temperaturas de cultivo $\left(15,30\right.$ e $\left.47^{\circ} \mathrm{C}\right)$ na adesão da Pseudomonas aeruginosa ATCC 27853 ao poliestireno.

Palavras-chave: Pseudomonas aeruginosa, temperatura, hidrofobicidade, adesão

\section{REFERENCES}

1. Bodey, G.P.; Bolivar, R.; Feinstein V.; Jadeja, L. Infections caused by Pseudomonas aeruginosa. Rev. Infect. Dis., 5, 279-293, 1983.

2. Briandet, R.; Meylheuc, T.; Maher, C.; Bellon-Fontaine M.N. Listeria monocytogenes Scott A: Cell Surface Charge, Hydrophobicity, and electron donor and acceptor characteristics under different environmental growth conditions. Appl. Environ. Microbiol., 65, 5328-5333, 1999. 
3. Busscher, H.J.; Weerkamp, A.H.; Van der Mei, H.C.; van Pelt, W.J.; De Long, H.P.; Arends, J. Measurement of the surface free energy of bacterial surface and its relevance for adhesion. Appl. Environ. Microbiol., 48, 980-983, 1984.

4. Cefali, E.; Patane, S.; Arena, A.; Saitta, G.; Guglielmino, S.; Cappello, S.; Nicolo, M.; Allegrini, M. Morphologic variations in bacteria under stress conditions: near-field optical studies. Scanning, 24(6), 274-83, 2002

5. Cowell, B.A.; Willcox, M.D.; Herbert, B.; Schneider, R.P. Effect of nutrient limitation on adhesion characteristics of Pseudomonas aeruginosa. J. Appl. Microbiol., 86, 944-954, 1999.

6. Delaquis, P.; Caldwell, D.E.; Lawrence, J.R.; McCurdy, A.R. Detachment of Pseudomonas fluorescens from Biofilms on glass surfaces in response to nutrient stress. Microbiol. Ecol., 18, 199210,1989

7. Donlan, R.M. Biofilms: Microbial Life on surfaces. Em. Infect. Dis., 8(9), 881-890, 2002.

8. Givskov, M.; Eberl, L.; Moller, S.; Kongsbak Poulsen, L.; Molin, S. Response to nutrient starvation in Pseudomonas. putida KT2442: Analysis of general cross-protection, cell shape and macromolecular content. J. Bacteriol., 176, 7-14, 1994.

9. Hartke, A.; Giard, J.-C.; LaPlace, J.-M.; Auffray Y. Survival of Enterococcus faecalis in an oligotrophic microcosm: changes in morphology, developement of general stress resistance, and analysis of protein synthesis. Appl. Environ. Microbiol., 4238-4245, 1996.

10. Hunt, S.M.; Werner, E.M.; Huang, B.; Hamilton, M.; Stewart, P.S. Hypothesis for the role of nutrient starvation in biofilm detachment. Appl. Environ. Microbiol., 70(12), 7418-7425, 2004.

11. James, G.A.; Korber, D.R.; Caldwell, D.E.; Costerton, J.W. Digital Image analysis of growth and starvation responses of a surfacecolonizing Acinetobacter sp. J. Bacteriol., 177, 907-915, 1995.
12. Jana, T.K.; Srivastava, A.K.; Csery, K.; Arora, D.K. Influence of growth and environmental conditions on cell surface hydrophobicity of Pseudomonas fluorescens in non-specific adhesion. Can. J. Microbiol., 46(1), 28-37, 2000.

13. Johson, K.; Lory, S. Characterization of Pseudomonas aeruginosa mutants with altered pilation. J. Bacteriol., 169, 5663-5667, 1987.

14. Jucker, B.A.; Harms, H.; Zehnder, A.J.B. Adhesion of the positively charged bacterium Stenotrophomonas (Xanthomonas) maltophilia 70401 to glass and teflon. J. Bacteriol., 178, 5472-5479, 1996.

15. Kjelleberg, S.; Humphrey, B.A.; Marschall, K. Initial phases of starvation and activity of bacteria st surface. Appl. Environ. Microbiol., 46, 978-984, 1983.

16. Makin, S.A.; Beveridge, T.J. The influence of A-band and B-band lipopolysaccharide and adhesion of Pseudomonas aeruginosa to surface. Microbiology, 142, 299-307, 1996.

17. Stanley, P.M. Factors affecting the irreversible attachement of Pseudomonas aeruginosa to stainless steel. Can. J. Microbiol., 29, 1493-1499, 1983.

18. Vanhaecke, E.; Remon, J.-P.; Moors, M.; Raes, F.; De Rudder, D.; Van Peteghem, A. Kinetics of Pseudomonas aeruginosa adhesion to 304 and 316-L stainless steel: role of cell surface hydrophobicity. Appl. Environ. Microbiol., 56, 788-795, 1990.

19. Vesterlund, S.; Paltta, J.; Karp, M.; Ouwehand, A.C. Adhesion of bacteria to resected human colonic tissue: Quantitative analysis of bacterial adhesion and viability. Res. Microbiol. Mar., 156(2), 238244,2005

20. Winstanley, C.; Coulson, M.A.; Wepner, B.; Morgan, J.A.W.; Hart, C.A. Flagellin gene and protein variation amongst clinical isolates of Pseudomonas aeruginosa. Microbiology, 142, 2145-2151, 1996.

21. Zhang, J.P.; Normark, S. Induction of gene expression in Escherichia coli after pilus-mediated adherence. Science, 273, 1234-1236, 1996. 